\title{
The analysis of the glyceride components on the treatment variation of refined bleached deodorized palm oil by gas chromatography method
}

\author{
${ }^{1,3}$ Zakwan, Z., ${ }^{2, *}$ Lubis, Z., ${ }^{4}$ Elisabeth, J. and ${ }^{2}$ Julianti, E. \\ ${ }^{1}$ Program Study of Teknologi Pengolahan Hasil Perkebunan, Sekolah Tinggi Ilmu Pertanian Agrobisnis \\ Perkebunan, Willem Iskandar, Medan, Indonesia \\ ${ }^{2}$ Program Study of Food Science and Technology, Faculty of Agriculture, Universitas Sumatera Utara, \\ Medan, Padang Bulan, Medan 20155, Indonesia \\ ${ }^{3}$ Doctoral Program of Agricultural Sciences, Faculty of Agriculture, Universitas Sumatera Utara, Padang \\ Bulan, Medan 20155, Indonesia \\ ${ }^{4}$ Politeknik Wilmar Bisnis Indonesia, Laut Dendang, Kapten Batu Sihombing Street, Percut Sei Tuan, Deli \\ Serdang, Sumatera Utara 20371
}

\begin{abstract}
Article history:
Received: 28 December 2020

Received in revised form: 18

February 2021

Accepted: 22 May 2021

Available Online: 5 February

2022
\end{abstract}

\section{Keywords:}

RBDPO,

Lipase enzyme,

Ester,

Gas chromatography,

Glyceride

DOI:

https://doi.org/10.26656/fr.2017.6(1).773

\begin{abstract}
The glyceride components such as glycerol, ester, mono and diglyceride are useful components for food ingredients like food emulsifiers. One of the natural resources of the glyceride component is refined bleached deodorized palm oil (RBDPO). This research was aimed to analyze the glyceride component of the treatment variation of RBDPO. The design of the research was completely randomized design (CRD) non-factorial with three variables of treatment specifically the $9 \mathrm{~g}$ of RBDPO with $5 \mathrm{~g}$ glycerol (A), RBDPO (B) and RBDPO with $0.7 \mathrm{~g}$ lipase enzyme Thermomyces lanuginosus immobilized (TLIM). The concentration of glycerol, ester, mono- and diglyceride was tested by the gas chromatography method. The data will be analyzed by using a descriptive method with a boxplot and histogram. The results showed that the highest concentration of glycerol, ester, mono- and diglyceride, respectively were shown in treatment B (1.5922\%), C $(9.5699 \%)$, C $(0.1783 \%), C(3.3329 \%)$. The boxplot graphic described that there was statistically significant difference among the treatments.
\end{abstract}

\section{Introduction}

The Refined Bleached Deodorized Palm Oil (RBDPO) is a derivative product of crude palm oil after having undergone a process of removing non-oil components such as free fatty acids, colloids, metals, pigments and aromas. The RBDPO is a triglyceride which at room temperature has two fractions, namely the liquid fraction (olein) and the solid fraction (stearin) (Subroto et al., 2018). The RBDPO was hydrolyzed naturally by heating treatment or adding other components like glycerol and lipase. Every one mole of the triglyceride that reacts with glycerol or lipase enzyme can produce monoglyceride (MG), diglyceride (DG) and the presence of excess glycerol. The processing of triglyceride at a high temperature leads to an equilibrium mixture of glycerol and esters (Affandi et al., 2011). The important use of the glyceride component such as glycerol, ester, mono and diglyceride are good emulsifiers for various food emulsions, such as margarine, shortening, mayonnaise and chocolate products. The alteration of glyceride components in RBDPO is obtained through hydrolysis, glycerolysis, esterification reactions using triglycerides, water, glycerol or alcohol as reactants with TLIM lipase as catalyst.

So, it is important to know the variation of the glyceride alteration in RBDPO both naturally, the addition of glycerol or lipase components. The variations in the treatment of the RBDPO need to be done to determine the various derivative products that can be obtained from the RBDPO especially in glyceride components (Santoso, 2016). Therefore, this research will study the analysis of the glyceride components on the treatment variation of refined bleached deodorized palm oil by gas chromatography method.

\section{Materials and methods}

2.1 Research design

The research was carried out from June - October 
2020. The place where the research was conducted was the Plantation Agribusiness College (STIPAP) and Universitas Sumatera Utara (USU).

The equipment used was a water bath shaker (Memmert), analytical scales (Sartorious), Erlenmeyer $100 \mathrm{~mL}$ (Pyrex), test tube, centrifuge (Centurion), centrifuge tube, refrigerator (Samsung), mesh filtration, Gas Chromatography (GC Series 2010 Plus, Shimadzu). Meanwhile, the materials used were Refined Bleached Deodorized Palm Oil (RBDPO), TL IM lipase enzyme (Novozyme), glycerin (Merck), alcohol (Technical), silica gel.

This study used a completely randomized design (CRD) Non-Factorial, with three variable treatments namely the $9 \mathrm{~g}$ of RBDPO with $5 \mathrm{~g}$ glycerol (A), RBDPO (B) and RBDPO with $0.7 \mathrm{~g}$ lipase enzyme TLIM. The products were tested by using gas chromatography apparatus and the results were analyzed.

\subsection{Analysis of data}

The results were analyzed descriptively using a chromatogram of GC, boxplot graph, then the differences were described by histograms.

\subsection{Research procedure}

The raw material was $9 \mathrm{~g}$ of RBDPO with a mixture of $5 \mathrm{~g}$ of glycerol in treatment $\mathrm{A}$, without mixture in treatment $\mathrm{B}$ and a mixture of $0.7 \mathrm{~g}$ of TL IM lipase enzyme in treatment $\mathrm{C}$. Then, $5 \mathrm{~mL}$ of alcohol $(85 \%$, technical) was added to each treatment. Then, the mixture was agitated at $60^{\circ} \mathrm{C}$ using a water bath shaker at $170 \mathrm{rpm}$ (Kaewthong et al., 2005) for $24 \mathrm{hrs}$ (Zakwan et al., 2017). The suspension formed was diluted with 10 $\mathrm{mL}$ of technical alcohol and separated using a centrifuge at $1000 \mathrm{rpm}$ (Zakwan et al., 2017) for 5 mins (Palacios et al., 2019).

\subsection{Gas chromatography}

The glyceride component was tested using the AOCS Cd 11b-91 method. Approximately $10 \mathrm{mg}$ of homogenized test sample pipetted into a $2.5 \mathrm{~mL}$ screwcap vial with Teflon ${ }^{\mathrm{TM}}$-face septa. At about $0.2 \mathrm{~mL}$ BSTFA (N, N-bis-trimethylsilyl-trifluoroacetamide) and $0.1 \mathrm{~mL}$ TMCS (Trimethylchlorsilane) and $0.1 \mathrm{~mL}$ of internal standard solution (tricaprin) was added. The moisture had to be excluded strictly. The vial was closed and shook vigorously. The reaction mixture was heated at $70^{\circ} \mathrm{C}$ for approximately 20 mins. At about $1-5 \mu \mathrm{L}$ of the reaction mixture was injected into the gas chromatography and analyzed (avoid the delay). The reaction was carried out two times and two injections are made. The reference solution: approximately $0.10 \mathrm{~mL}$ of the reference solution and the silylating agent, $0.2 \mathrm{~mL}$ BSTFA and $0.1 \mathrm{~mL}$ TMCS (no internal standard solution) was added. The reaction mixture was heated and injected into gas chromatography. The concentration range of reference standards similar to the range of the components was used to be quantified in the test solution. A plot of response vs. concentration of reference substances was useful to check linearity. The response factors had to be checked periodically (AOCS, 2020).

\section{Results and discussion}

\subsection{Determination of glyceride components using GC analysis}

Figure 1 was three chromatograms that verified the presence of the internal standard namely tricaprin used in this study at the same concentration, identified by its retention time. The result showed that the glycerol, esters and diglyceride were present at all chromatogram types, while the monoglyceride was only at chromatogram type C. According to Hobuss et al. (2020) that esters eluted between 10 and 16 mins retention time, monoglyceride appear in the range 17 mins, diglyceride appears after 27 mins and triglyceride was detected in chromatogram after 35 mins.

\subsection{The result of glyceride component tested}

The treatment had different levels of glycerol, esters, mono- and diglyceride that could be seen in Table 1 .

Table 1. The result of glyceride components tested by the Gas chromatography method

\begin{tabular}{ccccc}
\hline \multirow{2}{*}{ Treatment } & \multicolumn{4}{c}{ Glyceride components (\%) } \\
\cline { 2 - 5 } & Glycerol & Ester & MG & DG \\
\hline A & 1.5129 & 5.4753 & Undetected & 0.4763 \\
B & 1.5922 & 3.1583 & Undetected & 1.3491 \\
C & 0.6981 & 9.5699 & 0.1783 & 3.3329 \\
\hline
\end{tabular}

Treatment A: RBDPO with glycerol, Treatment B: RBDPO, Treatment $\mathrm{C}$ : RBDPO with lipase enzyme, MG: Monoglyceride, DG: Diglyceride.

Table 1 shows that the monoglyceride component was detected in treatment $\mathrm{C}$ at about $0.1783 \%$ but undetected in treatments A and B. The glycerol, ester, and diglyceride components could be detected in all treatments. The presence of esters was due to a heating treatment at $60^{\circ} \mathrm{C}$. Even without a catalyst, esters could still appear in heated carboxylic acids. Meanwhile, the use of a catalyst such as a lipase enzyme caused the formation of esters more consistently and higher. Mono and diglycerides were the products obtained before the reaction of ester formation ran completely. The glycerol was formed with esters formation (Otera and Nishikido, 2010). 

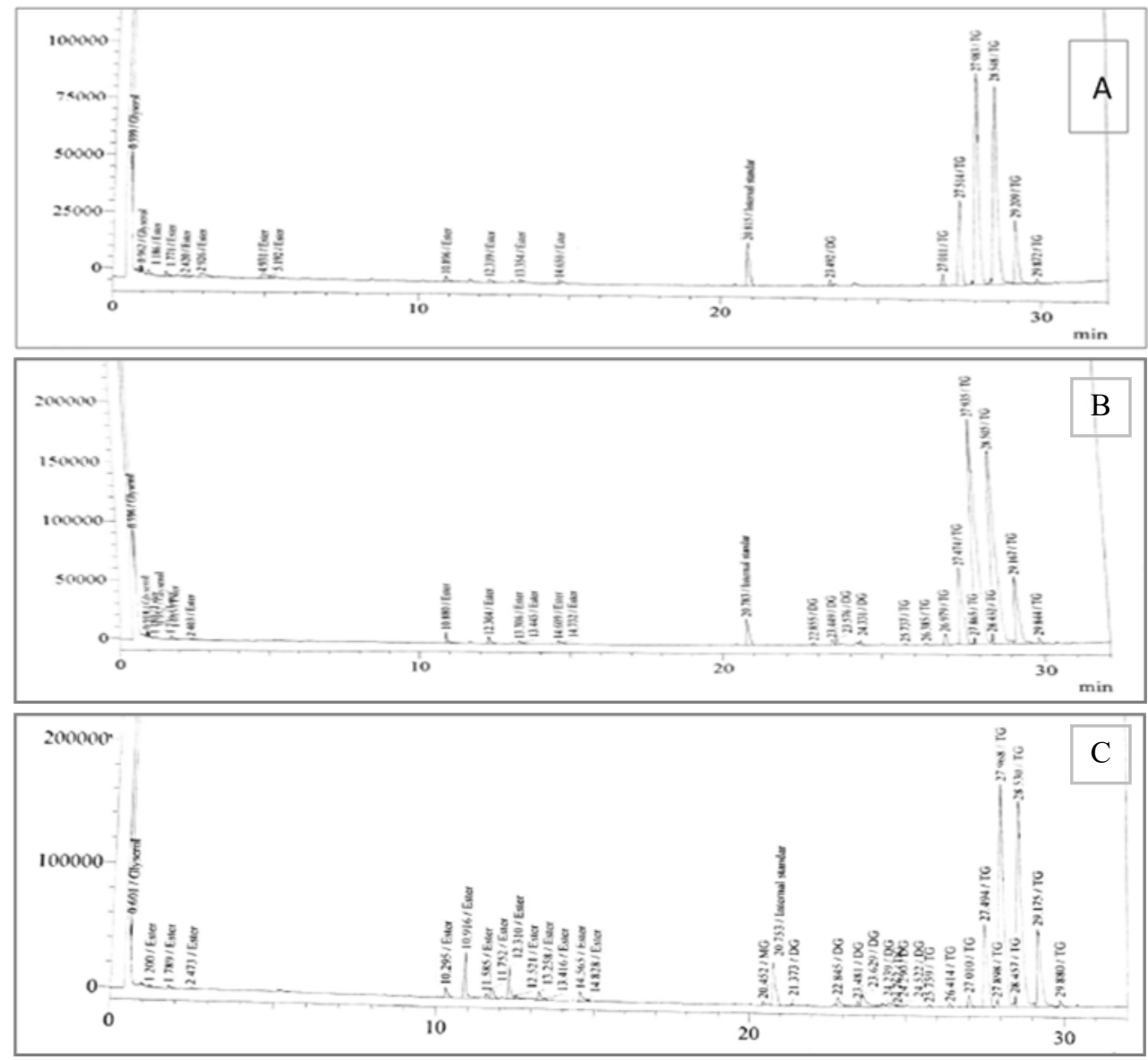

Figure 1. Chromatograms of (A) the RBDPO with glycerol, (B) the RBDPO, (C) the RBDPO with lipase enzyme.

In Figure 2, the boxplot in treatment $\mathrm{C}$ had a wide distribution (the highest interquartile) followed by treatment $\mathrm{A}$ and $\mathrm{B}$, respectively. The upper position of the boxplots was in treatment $\mathrm{C}$, which means that they generally had larger glyceride components in comparison to treatments A and B. Such evidence was also supported by the fact that the minimum value in treatment $\mathrm{C}$ was above the maximum value of treatment $\mathrm{A}$ and $\mathrm{B}$.

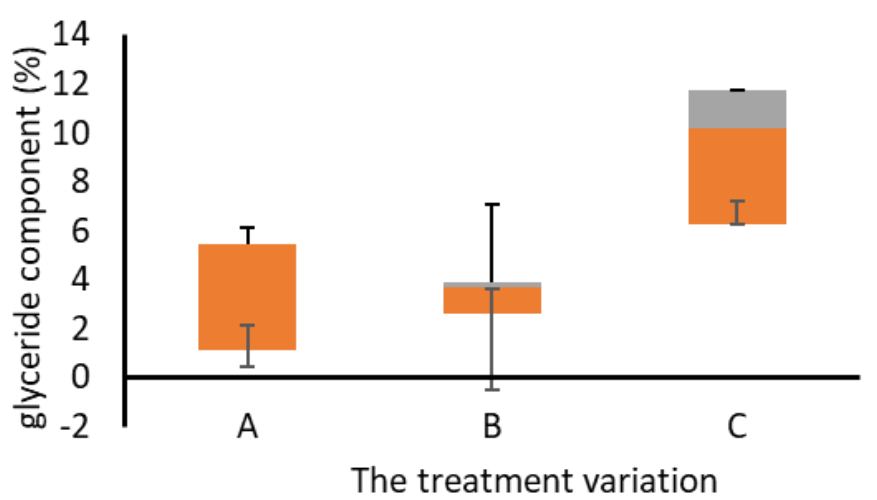

Figure 2. Boxplots for the variation of treatments of $A$ : RBDPO with glycerol, B: RBDPO and C: RBDPO with lipase enzyme.

In the median of each treatment variation, there were differences in the levels of glycerol, ester, monoglyceride, and diglyceride. Furthermore, from Figure 2 could be seen that there were no outliers. The boxplot of the ' $\mathrm{C}$ ' treatment showed that the vertical box was the highest one. It means that The ' $\mathrm{C}$ ' treatment had the more widespread data in the glyceride components (Ferreira et al., 2016). Figure 1 describes that the amount of the glyceride picks in the ' $\mathrm{C}$ ' chromatogram was the most one at about 17 peaks.

\subsection{The glyceride components and the treatment variation}

Figure 3 shows the differences of glycerol, ester, monoglyceride, and diglyceride in the variation of RBDPO treatment.

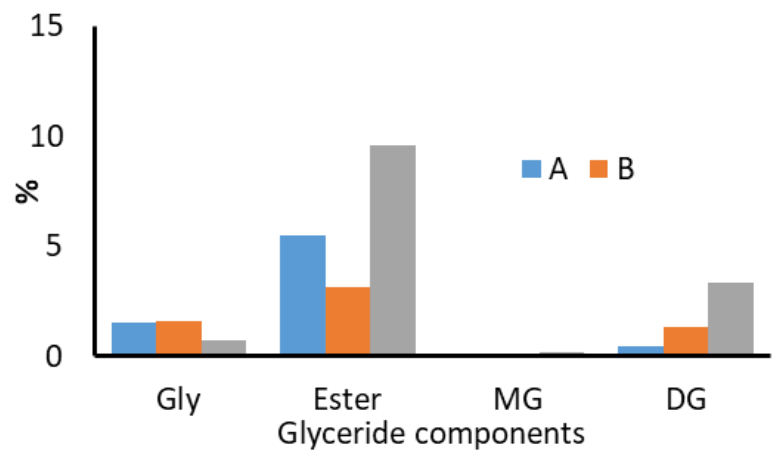

Figure 3. The concentration of glycerol (Gly), esters, monoglycerides $(\mathrm{MG})$ and diglycerides $(\mathrm{DG})$ in the variation of treatments of A: RBDPO with glycerol, B: RBDPO and C: RBDPO with lipase enzyme.

The glyceride components were glycerol $(0.7 \%)$, ester $(9.6 \%)$, monoglyceride $(0.2 \%)$ and diglyceride $(3.3 \%)$ in the ' $\mathrm{C}$ ' treatment (the RBDPO with lipase 
enzyme). Meanwhile, in the other treatments, monoglyceride components were not detected. It meant that the presence of the lipase enzyme was able to catalyze the RBDPO to produce monoglycerides. According to Wei et al. (2020), lipase could catalyze the formation of monoglycerides and diglycerides in triglyceride hydrolysis reactions.

The esters concentration in treatments $\mathrm{C}, \mathrm{A}$ and $\mathrm{B}$ were $9.57 \% ; 5.48 \%$ and $3.16 \%$, respectively. The highest ester component was found in treatment $\mathrm{C}$ (the RBDPO with lipase enzyme). This was according to the opinion of Otera and Nishikido (2010) who reported the use of the lipase enzyme caused the formation of esters to be faster in the equilibrium reaction.

\section{Conclusion}

The adding of the lipase enzyme to the refined bleached deodorized palm oil could catalyze the emergence of the glyceride components such as glycerol, ester, monoglyceride and diglyceride components. The ester level in the reaction using the lipase enzyme was higher than the reaction using the glycerol.

\section{Acknowledgement}

This research was supported by a grant (217/ UN5.2.3.1/PPM/SPP-TALENTA USU/2020) from the TALENTA research program 2020 of Universitas Sumatera Utara (USU). The author would like to thank to the Indonesia Ministry of Research, Technology and Higher Education for supporting by the Domestic Postgraduate Education Scholarships (BPPDN) program grant (B/67/D.D3/KD.02.00/2019).

\section{References}

Affandi, A.R., Andarwulan, N. and Hariyadi, P. (2011). Study of Mono and Diacylglycerol (MDAG) Synthesis by Glycerolysis Process in Pilot Plant Scale, presented at The National Conference of PATPI. Manado, Philippines: PATPI.

AOCS. (2020). Mono- and Diglycerides by Capillary Gas Chromatography (Cd 11b-91). USA: AOCS.

Ferreira, J.E.V., Pinheiro, M.T.S., dos Santos, W.R.S. and Maia, R.D.S. (2016). Graphical representation of chemical periodicity of main elements through boxplot. Educacion Quimica, 27(3), 209-216. https://doi.org/10.1016/j.eq.2016.04.007

Hobuss, C., DosSantos, M., DePereira, C., Schulz, G., Bianchini, D. and DaSilva, F. (2020). Synthesis and characterization of monoacylglycerols through glycerolysis of ethyl esters derived from linseed oil by green processes. RSC Advances, 10(4), 2327-

\section{6. https://doi.org/10.1039/C9RA07834G}

Kaewthong, W., Sirisansaneeyakul, S., Prasertsan, P. and H-Kittikun, A. (2005). Continuous production of monoacylglycerols by glycerolysis of palm olein with immobilized lipase. Process Biochemistry, 40 (5), 1525-1530. https://doi.org/10.1016/ j.procbio.2003.12.002

Otera, J. and Nishikido, J. (2010). Esterification Methods, Reactions and Application (Second). Weinheim, Germany: Wiley-VCH. https:// doi.org/10.1002/9783527627622

Palacios, D., Ortega, N., Rubio-Rodríguez, N. and Busto, M.D. (2019). Lipase-catalyzed glycerolysis of anchovy oil in a solvent-free system: Simultaneous optimization of monoacylglycerol synthesis and endproduct oxidative stability. Food Chemistry, 271, 372-379.

https://doi.org/10.1016/ j.foodchem.2018.07.184

Santoso, A. (2016). Sintesis Mono-Diasilgliserol (MDAG) dari Refined Bleached Deodorized Palm Oil (RBDPO) Dengan Metode Gliserolisis skala Pilot Plant. Retrieved on Dec 28, 2020 from https:// pdfs.semanticscholar.org/3896/57b6469d1192b5f77 653df62fe80a8c2ac47.pdf

Subroto, E., Faida Wisamputri, M., Utami, T. and Hidayat, C. (2018). Enzymatic and chemical synthesis of high mono-and diacylglycerol from palm stearin and olein blend at different type of reactor stirrers. Journal of the Saudi Society of Agricultural Sciences, 19(1), 31-36. https:// doi.org/10.1016/j.jssas.2018.05.003

Wei, W., Sun, C., Wang, X., Jin, Q., Xu, X., Akoh, C.C. and Wang, X. (2020). Lipase-Catalyzed Synthesis of Sn-2 Palmitate: A Review. Engineering, 6(4), 406414. https://doi.org/10.1016/j.eng.2020.02.008

Zakwan, Z. Julianti, E. and Lubis, Z. (2017). Production mono-diglyceride (MDG) from refined deodorized palm oil (RBDPO) by enzymatic process. International Food Research Journal, 24(1), 56-59. 